\title{
KOMPLEKSITAS RUANG PUBLIK (PUBLIC SPACE): AGORA, YUNANI DAN FORUM, ROMAWI
}

\author{
Yosica Mariana \\ Architecture Department, Faculty of Engineering, Binus University \\ Jl. K.H. Syahdan No. 9, Palmerah, Jakarta Barat 11480 \\ mariana_yosica@binus.ac.id
}

\begin{abstract}
The city that grows unplanned usually arises because of the conurbations of a culture, such as Agora in Greek and Forum in Roman. The "unplanned" city grows in strategic places, such as around the harbor, business places, worship places, or other activity centers. The city growth due to cultural centers is usually characterized by the growth of services as the economic support of the city activities. The service center develops a community center in the form of public facilities, such as public spaces and public buildings. Western understanding about this kind of design is oriented to functional vision illustrated from several illustrations of history that developed in the world of architecture. Understanding of cosmology in typology and morphology that affect the built environment, especially the face of a city, can be described by reviewing some of the phenomena that have been developed in connection with cosmological concept that affects the embryo of market formation, ie public open spaces which became the center of city residents to the commercial, political, recreational activities, and others resulting from the interaction of community activities.
\end{abstract}

Keywords: cosmological concept, open spaces, community

\begin{abstract}
ABSTRAK
Kota yang berkembang secara tidak terencana biasanya terjadi karena proses konurbasi dari suatu kebudayaan, seperti Agora (Yunani) dan Forum (Romawi). Kota ini berkembang pada tempat yang strategis, misalnya di sekitar pelabuhan, tempat usaha, tempat peribadatan, atau pusat kegiatan lainnya. Tumbuhnya kota akibat kebudayaan biasanya dicirikan dengan tumbuhnya pusat jasa sebagai urat nadi perekonomian penyokong kegiatan kota tersebut. Pusat jasa yang berkembang melahirkan suatu pusat komunikasi berupa fasilitas public, seperti ruang publik maupun gedung publik. Pemahaman Barat tentang rancang bangun seperti ini berorientasi ke visi fungsional. Fenomena ini tergambar dari beberapa ilustrasi sejarah yang berkembang pada dunia arsitektur. Pemahaman kosmologi secara tipologi dan morfologi yang mempengaruhi lingkungan binaan khususnya wajah suatu kota, dapat diuraikan dengan meninjau beberapa fenomena yang telah berkembang sehubungan dengan konsep kosmologi yang mempengaruhi embrio (benih awal) terbentuknya pasar, yaitu ruang terbuka umum yang menjadi pusat kegiatan warga kota untuk aktivitas niaga, politik, rekreasi, dan kegiatan lainnya akibat dari hasil interaksi kegiatan masyarakat.
\end{abstract}

Kata kunci: Pemahaman kosmologi, ruang terbuka, masyarakat 


\section{PENDAHULUAN}

Pada jaman pertengahan, ruang-ruang kota didominasi oleh gereja dan kastil bangsawan. Plaza disamping halaman gereja juga berfungsi sebagai market place. Ruang terbuka, jalan dan plaza dibangun terintegrasi dengan bangunan di sekelilingnya. Agora merupakan embrio atau benih awal terbentuknya suatu pasar, berupa ruang terbuka umum yang menjadi pusat kegiatan warga kota untuk aktivitas niaga, politik, rekreasi dan kegiatan lainnya akibat dari interaksi kegiatan yang dilakukan oleh masyarakat. Agora berkembang pula menjadi pusat dilangsungkannya suatu kegiatan peribadatan. Agora merupakan pangkal tolak lahirnya urban space (ruang perkotaan). Agora terletak di Athena, diatur dalam tatanan ruang kota, yang dikelilingi oleh bangunan-bangunan penting termasuk pusat rekreasi dan bangunan pemerintahan. Kemudian dalam perkembangannya, Agora berkembang sebagai tempat bermasyarakat (ruang bersosialisasi), sedangkan pusat pemerintahan sendiri berpindah ke Acropolis.

Sejak jaman Yunani pembentukan kotaadalah suatu kreasi yang ditujukan untuk manusia, yang kemudian diikuti oleh kebudayaan Romawi yang lebih maju, serta diekspresikan lebih baru lagi pada kota-kota abad pertengahan. Pada masa Romawi kuno, menggunakan skema konsolidasi untuk perencanaan kota, dengan dikembangkan untuk pertahanan militer dan kenyamanan sipil. Rencana dasar terdiri dari sebuah Forum pusat dengan layanan kota, dikelilingi oleh grid, kompak, jalanberbentuk bujursangkar, dan dibungkus dalam sebuah dinding untuk pertahanan. Untuk mengurangi waktu perjalanan, dua jalan diagonal melintasi kisi persegi, melewati alun-alun pusat, sungai biasanya mengalir melalui kota, dan digunakan untuk penyediaan air, transportasi, dan pembuangan limbah. Banyak kota-kota Eropa, seperti Turin, melestarikan sisa-sisa model kota seperti ini, yang menunjukkan cara yang sangat logis Roma dirancang kota-kota mereka. Mereka akanlay-out jalan-jalan di sudut kanan, dalam bentuk kotak persegi. Semua jalan yang sama lebar dan panjang, kecuali dua, yang sedikit lebih lebar dari yang lain.

\section{Tinjauan Pustaka}

\section{Urban Desain (Urban Design)}

Fokus dari urban desain yaitu pada pengaturan penampilan/tampilan dari fungsi kota, dan khususnya dalam pembentuk dan penggunaan ruang publik kota. Secara konvensional urban desain dapat dianggap bagian dari disiplin perencanaan kota dan arsitektur lansekap. Bersamaan dengan perkembangan ilmu pengetahuan, urban desain lebih dikonseptualisasikan sebagai gabungan dari beberapa disiplin ilmu (arsitektur perkotaan, arsitektur lansekap, dll) ditambah dengan pemahaman tentang berbagai disiplin yang lain seperti pembangunan perumahan, ekonomi perkotaan, ekonomi politik dan teori sosial.

Teori urban desain terutama berkaitan dengan desain dan pengelolaan ruang publik (sebagai contoh lingkungan publik) serta bagaimana ruang publik tersebut digunakan. Ruang publik mencakup totalitas ruang yang dapat digunakan secara bebas setiap hari oleh masyarakat umum, seperti jalan, plaza, taman dan infrastruktur publik. Beberapa aspek ruang, seperti fasad bangunan atau halaman sekitar fasad, juga berkontribusi terhadap ruang publik.

Walaupun kedua bidang yaitu urban desain dan perencanaan kota berkaitan erat satu sama lain, penerapan urban design (urban desain) berbeda dengan urban planning (perencanaan kota). Urban desain lebih berfokus pada perbaikan fisik lingkungan public, sedangkan perencanaan kota lebih berfokus pada manajemen pengembangan kota melalui metode dan program perencanaan yang ditetapkan termasuk pengontrolan dalam pembangunannya. Dalam pekerjaannya, para desainer urban tidak dapat berdiri sendiri karena perlu melibatkan berbagai interdisiplin seperti insinyur, ekologis, 
perencana transportasi dan sejarawan.Urban desain dapat meliputi penyusunan pedoman desain dan kerangka peraturan kerja atau bahkan undang-undang untuk mengendalikan pengembangan, periklanan dan lain-lainnya, juga menangani mengenai 'manajemen pengelolaan'dalam membantu penggunaan dan pemeliharaan daerah perkotaan dan ruang publik. Beberapa hal yang dipertimbangkan dalam urban desain sebagaimana dikutip dari Wikipedia (2011) yaitu: (1) urban struktur (urban structure), bagaimana 'place' diletakkan bersama-sama dan bagaimana bagianbagiannya berhubungan satu dengan yang lainnya; (2) urban tipologi, kepadatan dan kesinambungan (urban typology, density and sustainability) - jenis dan morfologi ruang berkaitan dengan intensitas penggunaan lahan, konsumsi sumber daya dan produksi serta pemeliharaan yang layak bagi masyarakat; (3) aksesibilitas (accessibility) - menyediakan kemudahan, keselamatan dan pilihan ketika hendak pindah ke dan atau melalui berbagai tempat; (4) kejelasan dan penyelesaian masalah (legibility and wayfinding) - membantu orang untuk menemukan jalan di sekitar ruang public dan memahami bagaimana kondisi dan keadaan tempat mereka berada; (5) animasi (animation) - merancang tempat yang merangsang kegiatan publik masyarakat; (6) Fungsi dan kecocokan (Function and fit) membentuk tempat yang dapat mendukung penggunaan berbagai fungsi; (7) pelengkap fungsi campuran (Complementary mixed use)-fungsi campuran yang dapat menimbulkan interaksi yang konstruktif antara mereka; (8) karakter dan makna (character and meaning) - pengakuan dan penghargaan terhadap perbedaan antara satu tempat dengan yang lainnya; (9) keteraturan dan kejadian (order and incident) - konsistensi keseimbangan dan variasi dalam lingkungan perkotaan dalam kepentingan menghargai keduanya; (10) kesinambungan dan perubahan (continuity and change) penempatan manusia pada waktu dan tempat yang tepat, termasuk dalam menghormati warisan leluhur dan dukungan untuk budaya kontemporer; (11) masyarakat sipil (civil society) - menciptakan tempat di mana orang bebas untuk bertemu satu sama lain sebagai warga negara sama, merupakan sebuah komponen penting dalam membangun modal sosial.

Urban desain melibatkan penataan dan desain bangunan, ruang publik, sistem transportasi, jasa, dan fasilitas. Urban desain adalah proses memberikan bentuk dan karakter untuk kelompok bangunan, untuk lingkungan secara keseluruhan, dan kota. Ini adalah kerangka kerja yang melibatkan berbagai elemen ke dalam jaringan jalan, kotak, dan blok. Perkotaan memadukan desain arsitektur, arsitektur lanskap, dan perencanaan kota bersama-sama untuk membuat daerah perkotaan fungsional dan menarik.

Urban desain adalah tentang membuat hubungan antara orang dan tempat, gerakan dan bentuk kota, alam sertaamplop bangunan. Urban desain membentuk ruang, secara bersama dengan pengelolaan lingkungan hidup, keadilan sosial dan kelayakan ekonomi dalam pembentuk ruang dengan keindahan yang berbeda dan beridentitas.

Proses ini dicapai dengan membangun lingkungan yang dapat diidentifikasi, arsitektur yang unik, estetis yang menyenangkan, tempat-tempat umum dan pemandangan, landmark diidentifikasi dan titik fokus, dan elemen pembangunan dan pelayanan publikyang disesuaikan dengan skala manusia. Elemen kunci pembentuk ruanglainnya meliputi: pusat komersial hidup, pengembangan penggunaan fungsi campuran dengan menggunakan ritel di lantai dasar, skala manusia dan desain konteks-sensitif; tempat umum yang aman dan menarik, menciptakan imaginasi dan elemen dekoratif di wilayah publik. Beberapa urban desain dalam skala ruang publik kecil (jalan) untuk lingkungan, sistem ruang perkotaan dan seluruh wilayah perkotaan sebagai berikut (Gambar 1):

\section{Ruang Perkotaan (Urban Space)}

Krier (1979) dalam buku "Urban Space” mengatakan bahwa jika tidak memperhatikan aspek estetika, ruang perkotaan menunjuk pada semua jenis ruang antara bangunan di kota-kota dan daerahnya. Ruang ini dibatasi secara geometris dengan berbagai elevasi. Dengan kejelasan tentang karakteristik geometri dan kualitas estetika, membuat kita sadar untuk melihat ruang eksternal sebagai ruang perkotaan (urban space). Ruang internal dan eksternal mematuhi hukum yang sangat mirip tidak 
hanya pada fungsi tetapi juga dalam bentuk.Untuk ruang internal, terlindung dari cuaca dan memiliki lingkungan yang privasi, sedangkan ruang eksternal bersifat terbuka, pergerakannya tidak terhalang, dengan konsep publik, semi publik bahkan privat.
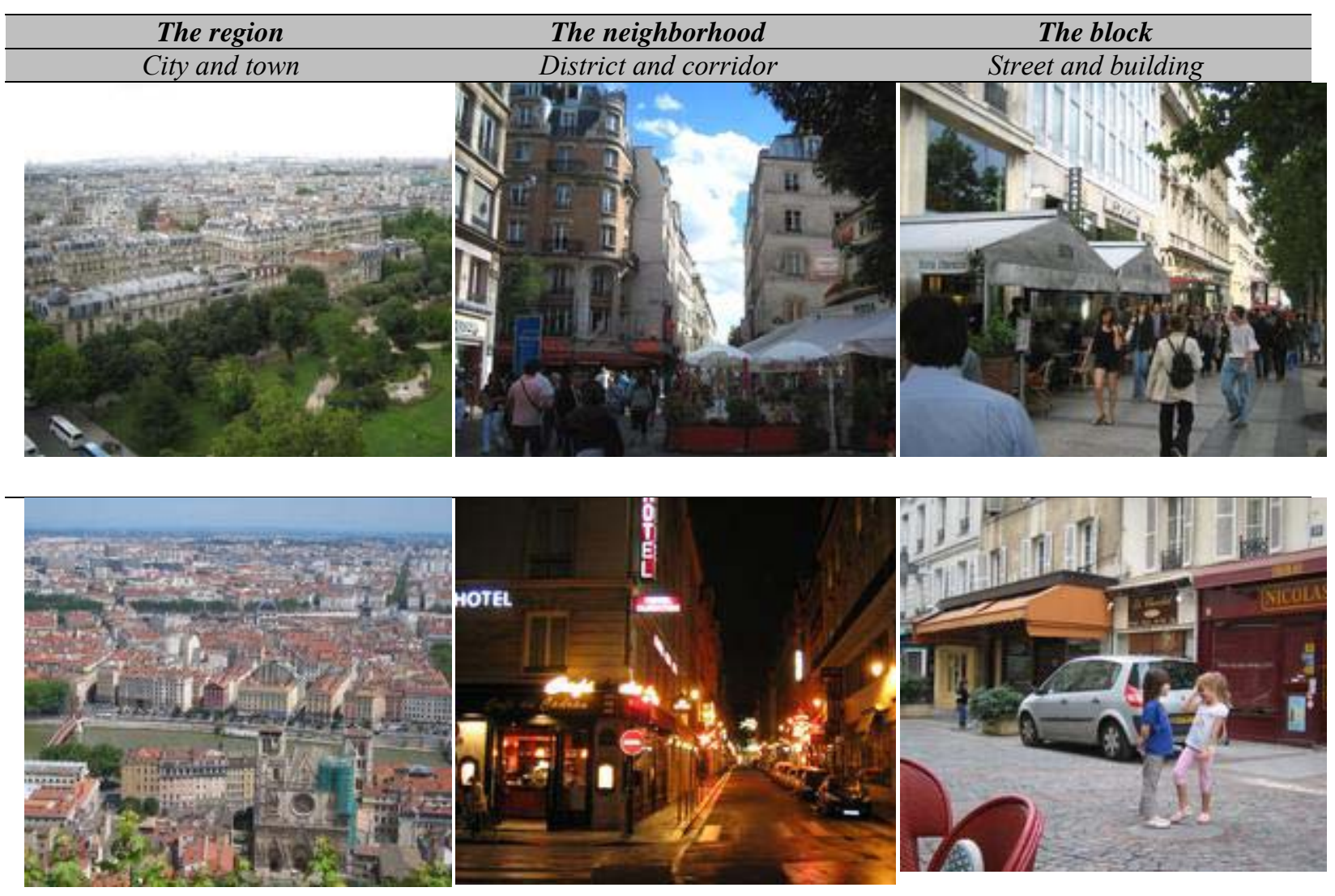

Gambar 1. Skala Urban Desain (Google.com, 2010)

Ruang kota mempunyai bentuk-bentuk dasar dengan kemungkinan variasi dan kombinasi dalam jumlah terbatas. Kualitas estetika dari setiap elemen ruang perkotaan ditandai dengan keterkaitan pada struktural detail. Dua unsur dasar ruang perkotaan yaitu street (jalan) dan alun-alun (alun-alun). Sedangkan dalam skala interior yang dibicarakan adalah koridor dan ruangan. Karakteristik geometri dari kedua bentuk spasial adalah sama, hanya dibedakan oleh dimensi dinding yang mengikat mereka dan oleh pola fungsi dan sirkulasi yang mencirikan mereka. Kemungkinan besar alun-alun merupakan hal pertama yang didesain orang dalam penggunaan ruang kota. Pada awalnya alun-alun terbentuk dari pengelompokan rumah di sekitar ruang terbuka. Hal ini dihasilkan oleh pengelompokan rumah di sekitar ruang terbuka. Alun-alun sering digunakan sebagai simbolis keagamaan (Agora, Forum, cloister, mosque, courtyard).

Sementara jalan merupakan ruang yang terbentuk dari penyebaran rumah dan bangunan yang dibangun di semua ruang yang tersedia di sekitar alun-alun. Ini menyediakan kerangka kerja untuk pendistribusian lahan dan memberikan akses ke bangunan. Jalan memiliki karakter yang lebih jelas dan fungsional daripada alun-alun. Dan berdasarkan ukurannya, jalan merupakan tempat yang menarik untuk melewatkan waktu dan menikmati suasana. Ukuran yang dipakai merupakan skala manusia, jalan ini direncanakan untuk sirkulasi dan aktivitas manusia serta tidak cocok untuk arus lalu lintas kendaraan bermotor. 


\section{Ruang Publik (Public Space)}

Ruang terbuka publik di pusat kota dalam istilah Inggris disebut "place", yang berasal dari kata latin "platea" yang berarti ruang terbuka publik atau jalan yang diperlebar seperti pada "plaza" di Spanyol atau "piazza" di Italia atau kata yang lebih khusus seperti alun-alun atau "square". Paul Zucker (1959), menyatakan bahwa alun-alun adalah tempat orang-orang berkumpul untuk bersosialisasi, melindungi mereka dari hiruk-pikik lalu-lintas, membebaskan mereka dari tekanan kesibukan di pusat kota. Michael Webb (1990), beranggapan bahwa alun-alun adalah mikrokosmos dari kehidupan, menawarkan daya tarik, peristirahatan, pasar dan upacara rakyat; tempat untuk berjumpa teman dan menghabiskan waktu. Cliff Moughtin (1992) menemukan bahwa alun-alun adalah areal yang dibingkai oleh bangunan-bangunan untuk memamerkan bangunan tersebut sebagai karya agung. Selanjutnya dinyatakan bahwa sebuah kota harus memilki ruang untuk penempatan bangunan umum, tempat bertemu, tempat untuk perayaan atau upacara umum yang besar, tempat pertunjukan: restoran dan café, tempat untuk berbelanja: pasar dan etalase, tempat dimana bangunan kantor mengelompok, tempat akomodasi rumah tinggal, tempat yang berhubungan dengan simpulsimpul transportasi. Rob Krier (1979), menyatakan bahwa suatu alun-alun harus dapat berfungsi sebagai tempat aktifitas komersial, seperti pasar, kegiatan budaya, tempat berdirinya kantor pelayanan umum, balai kota, gelanggang remaja, perpustakaan, teater, balai konser, kafe, bar, dan lain-lain. Jika memungkinkan, alun-alun di pusat kota harus dapat berfungsi 24 jam sehari. Dari beberapa pengertian tentang alun-alun diatas dapat disimpulkan bahwa alun-alun (square) bukanlah suatu ruang terbuka publik biasa yang ada di daerah urban, melainkan suatu ruang terbuka publik di pusat kota dengan suatu ciri khas tersendiri. Tidak semua ruang terbuka publik di daerah urban dapat digolongkan sebagai alun-alun. Pengertian alun-alun dapat diterjemahkan menjadi ruang terbuka publik di pusat kota, yaitu ruang terbuka yang mempunyai ciri antara lain: (1) berada di pusat kota; (2) berupa ruang terbuka yang cukup luas (Spiro Kostof, 2005, p.136, merujuk Laws of Indies yang mengatur ukuran minimum square $61 \times 91 \mathrm{~m}$ ); (3) menjadi pusat kegiatan publik di pusat kota (Moughtin 1992); (4) pilihan utama masyarakat kota untuk tempat berkumpul, di sekitarnya terdapat bangunan-bangunan publik dan atau bangunan religius, merupakan bagian dari bentukan arsitektur yang ada disekelilingnya (Kostof, 2005); (5) mempunyai signifikansi sejarah, dapat mengakomodasi parkir, dimungkinkan untuk melakukan kegiatan komersial non-formal, kadangkala ia berisi suatu monumen utama, patung atau air mancur (Marcus 1998); (6) memiliki nilai politik (sebagai lambang kekuasaaan atau tempat bertemuwarga dengan penguasa/pemerintah).

\section{HASIL DAN PEMBAHASAN}

Bacon (1976) dalam bukunya Design of Cities mengatakan bahwa kota merupakan hasil dari manusia, yang dipengaruhi oleh budaya dan adat istiadat. Bentuk perkotaan yang harmonis, bila elemen-elemen kota diatur dan dapat meningkatkan pergerakan orang melalui ruang. Suatu bentuk perkotaan yang berkembang sukses dikatakan ketika setiap lapisan bangunan baru dimasukkan dengan hati-hati ke dalam lapisan/amplop perkotaannya.

\section{Perkembangan Ruang Publik Pada Masa Yunani}

Pada masa Yunani kuno, bangunan tumbuh secara tidak teratur, ruang-ruang terbuka diadakan karena sistem politik di Yunani bersifat demokratis (menghargai hubungan manusia dengan alam), sehingga membutuhkan tempat untuk bersosialisasi berupa ruang publik (public space). Proses perkembangan ruang publik pada jaman Yunani sebagai berikut (Gambar 1). Tahun 500 SM, berawal dari bangunan kecil tidak menyatu secara visual (Gambar 1). Terdapat jalan yang melintas tempat perdagangan, bangunan pemerintahan dan dewan serta kuil. Tahun $420 \mathrm{SM}$, bangunan menjadi lebih panjang dan lebih teratur yang mengelilingi ruang terbuka (Gambar 2). Periode Hellenistic: Agora 
semakin jelas dalam perkembangannya (Gambar 3). Abad ke-2 M: Agora telah termodifikasi akibat tekanan pertumbuhan kehidupan warga kota (Gambar 4).

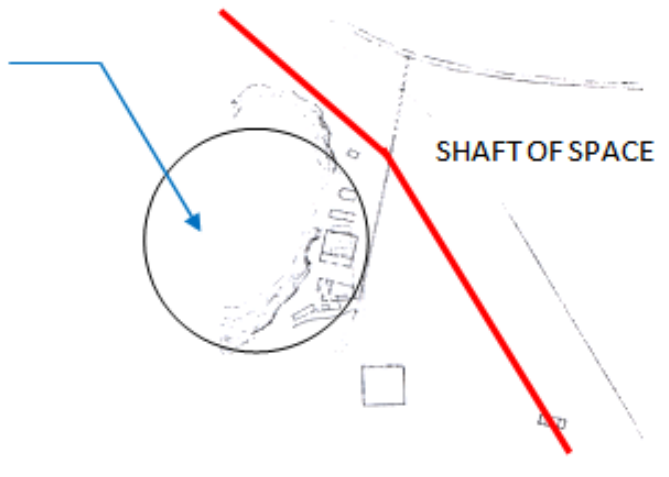

Gambar 1. Bangunan kecil tidak menyatu secara visual.

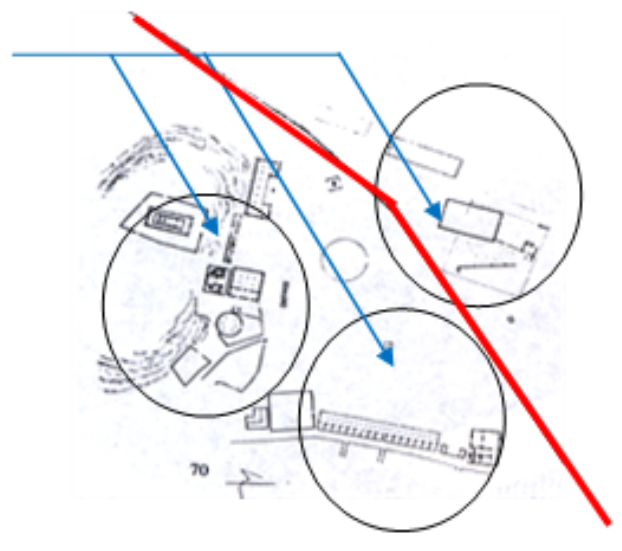

Gambar 2. Bangunan menjadi lebih panjang dan lebih teratur yang mengelilingi ruang terbuka.

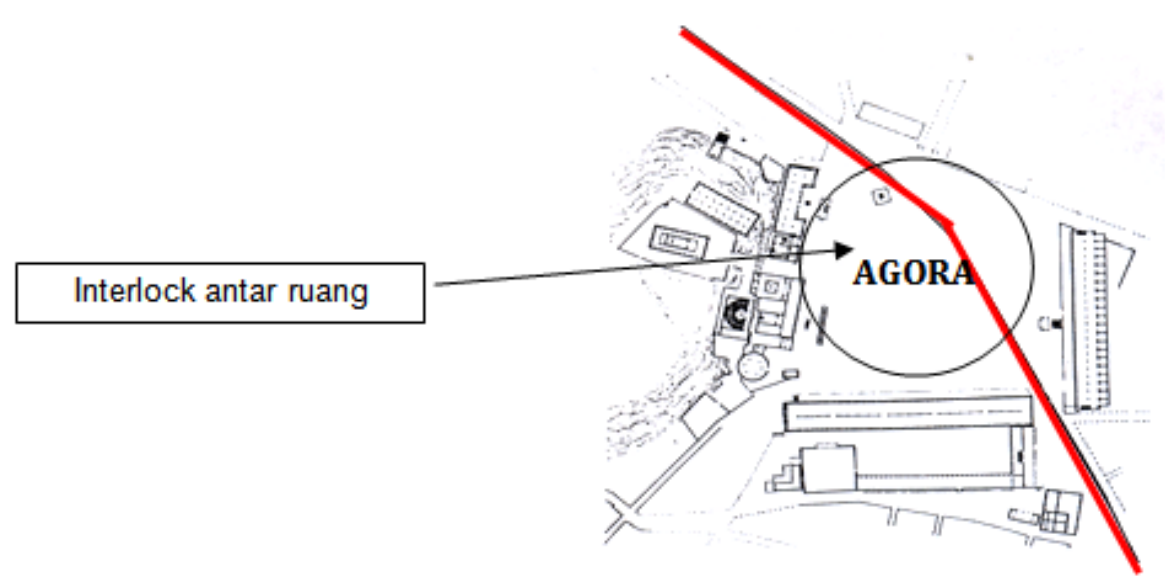

Gambar 3. Perkembangan Agora semakin jelas pada Periode Hellenistic.

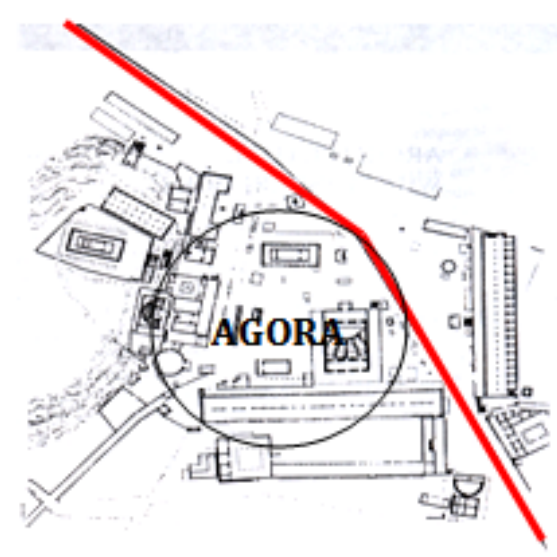

Gambar 4. Agora telah termodifikasi akibat tekanan pertumbuhan kehidupan warga kota. 
Agora (bahasa Yunani: Ápopó, Agorá) adalah tempat untuk pertemuan terbuka di Yunani kuno (Gambar 5). Pada awal sejarah Yunani, (900-700 SM), orang merdeka dan pemilik tanah yang berstatus sebagai warga negara berkumpul di Agora untuk bermusyawarah dengan raja atau dewan. Di kemudian hari, Agora juga berfungsi sebagai pasar tempat para pedagang menempatkan barang dagangannya di antara pilar-pilar Agora. Dari fungsi ganda ini, muncullah dua kata dalam bahasa Yunani: $\alpha \gamma o \rho \alpha ́ \zeta \omega$, agorázō, "aku berbelanja", dan $\alpha \gamma o \rho \varepsilon v ́ \omega$, agoreýo, "aku berbicara di depan umum". Agora terbentuk dengan ciri-ciri sebagai berikut: (1) bangunan-bangunan pada Agora memperlihatkan sebagai facade yang membentuk ruang kota yang tertutup, dimana sekelilingnya merupakan suatu arcade; (2) dibentuk dalam waktu yang cukup lama; (3) merupakan ruang urban pertama dan terpenting sebagai tempat masyarakat bertemu, berinteraksi sosial (kegiatan dagang dan kehidupan politik); (4) ide Agora baik sebagai "place" maupun "space" merupakan satu kesatuan sebagai konsep yang sangat berguna di dalam urban design; (5) ruang yang terbentuk secara visual berupa keseimbangan asimetrik-dibentuk oleh gabungan detail yang mirip; (6) merupakan ruang terbuka dengan fungsi yang lebih terklasifikasi; (7) bentuk Agora umumnya geometris dengan luas sekitar 5\% dari luas kota.

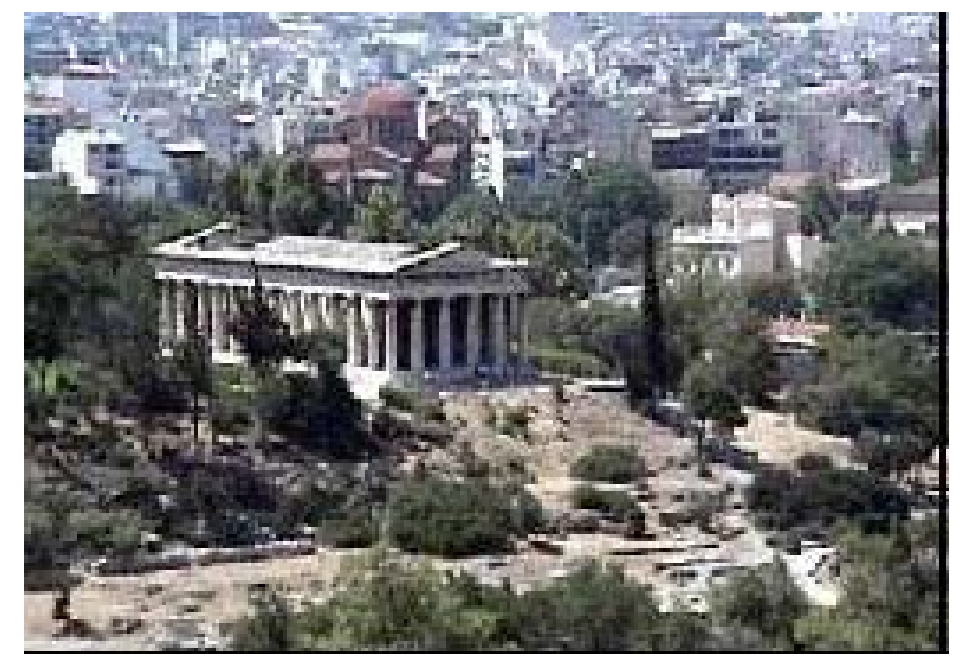

Gambar 5. Agora, Yunani Kuno (Sumber: Onlyrooms.com, 2009).

\section{Priene, Turki (abad ke-4 SM)}

Perkembangan kota ini mengikuti skema Hippodamus, dengan pola jalan grid. Dinding kota mengikuti kontur sebagai pertahanan terhadap serangan musuh. Agora terletak di tengah (Gambar 6) yang dibentuk oleh stoa dan yang berfungsi sebagai tempat berniaga. Satu di antara jalan utama secara langsung menuju Agora. Terdapat kuil dan teater yang berdekatan dengan Agora. Di sudut Agora terdapat kuil kecil Zeus.

\section{Delos}

Kota Delos dibangun oleh bangsa Yunani di suatu pulau dikelilingi laut Aegean yang terdiri dari sejumlah bentuk teratur yang satu sama lain terhubungkan. Jantung kota Delos adalah Agora dan kuil yang behadapan dengan teluk, akan tetapi orientasi ruang menuju ke dalam (Gambar 7). 


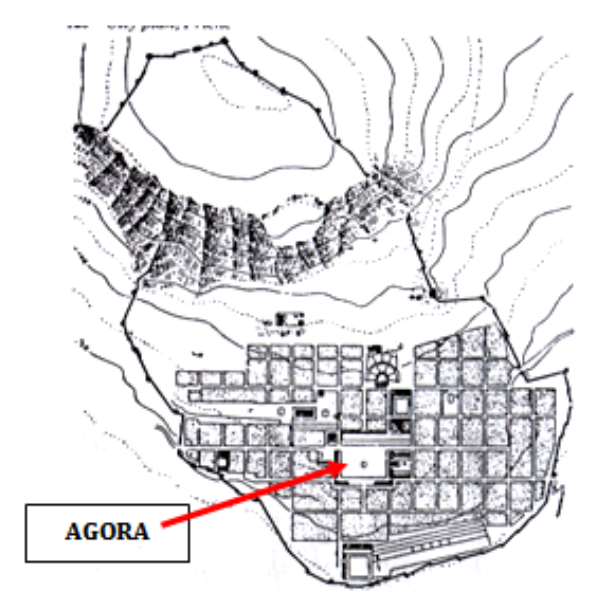

Gambar 6. Letak Agora di tengah kota Priene.

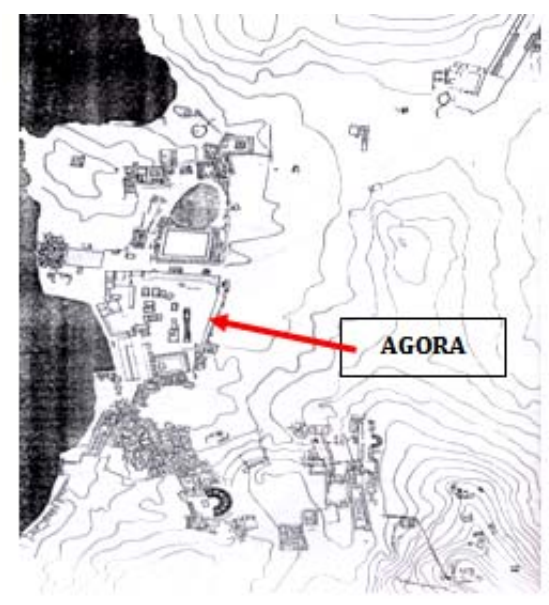

Gambar 7. Letak Agora di kota Delos.

\section{Perkembangan Ruang Publik Pada Masa Romawi}

Sementara itu di Romawi, tatanan bangunan sangat dipengaruhi oleh sistem pemerintahan yang unggul di bidang militer. Pembuatan ruang-ruang sering muncul karena latar belakang strategi untuk menjebak musuh, seperti gerbang benteng (sistem castrum), salah satu ciri khas kota militer Romawi. Romawi juga terkenal dengan masyarakat kosmopolitan yang pertama, dimana pemerintahannya sangat memanjakan masyarakatnya dengan fasilitas baru, misalnya fasilitas olah raga, tempat pertemuan dan tempat hiburan. Sistem grid juga mulai dipakai seperti pola pemukiman berbentuk kuadran. Pada abad pertengahan,di Romawi timbul gejala dimana Gereja menjadi pusat kekuasaan. Dalam tatanan arsitektur, gereja sebagai bangunan utama (focal point), dan pemukiman penduduk berkembang di sekitarnya. Tanah pertanian pada umumnya berkembang di luar benteng. Benteng-benteng dibuat untuk keperluan pertahanan, sehingga polanya organis, tanpa pola hirarkhi yang jelas. Jalan pada umumnya sempit dan berbentuk lorong untuk menjebak musuh. Pertemuan lorong membentuk node, sebagai tempat warga beraktivitas. Ruang terbuka berupa halaman depan gereja yang disebut parvis, yang berguna sebagai tempat umat berkumpul. Hal ini merupakan kemunduran dari masa sebelumnya (periode klasik), yang telah mengenal public facility.

\section{Kota Kolonial Romawi atau Kota Militer}

Kota kolonial Romawi adalah sistem jalan-gridion yang di kelilingi dinding. Dinding dibangun pertama kali, kemudian bangunan dibangun kemudian. Secara tradisional, permukaan tanah diratakan sebelum dibangun dinding, mungkin untuk membentuk pola kota yang seperti "garis lurus". Kota kolonial dengan menekankan pola jalan, memperkenalkan gagasan klasifikasi jalan mayor dan minor, yang dinamakan sumbu "cardo" dan "decomanus" yang membagi kota menjadi empat bagian. Sistem perancangan kota tersebut sederhana tetapi mempunyai pola yang terorganisir dengan baik untuk bangunan-bangunan di dalamnya. Tempat publik dibangun teater, arena dan pasar, yang terletak pada sumbu kota, tetapi hanya sebagai bagian dari wilayah kota dan menjadi bagian elemen kota. Gambar 8 merupakan ilustrasi tata letak kota Kolonial Romawi.

\section{Forum}

Forum (Latin: Forum, Italia: Foro) adalah pusat kehidupan publik Romawi sebagai tempat prosesi kemenangan dan pemilihan, tempat untuk pidato publik dan inti urusan komersial, yang berbentuk sebuah persegi panjang dikelilingi oleh gedung-gedung pemerintah di pusat kota (Gambar 9). 


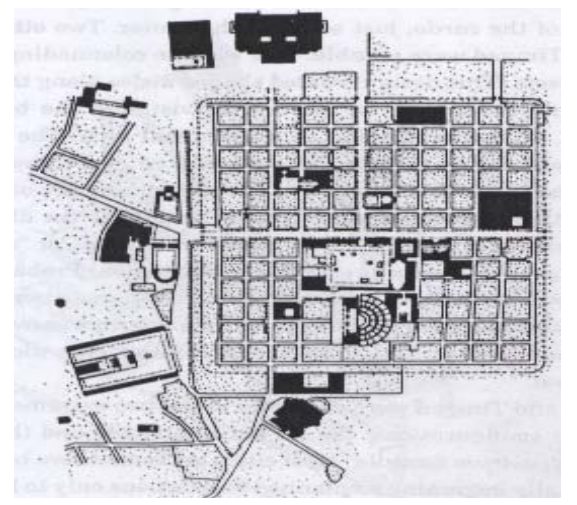

Gambar 8. Tata letak kota Kolonial Romawi.

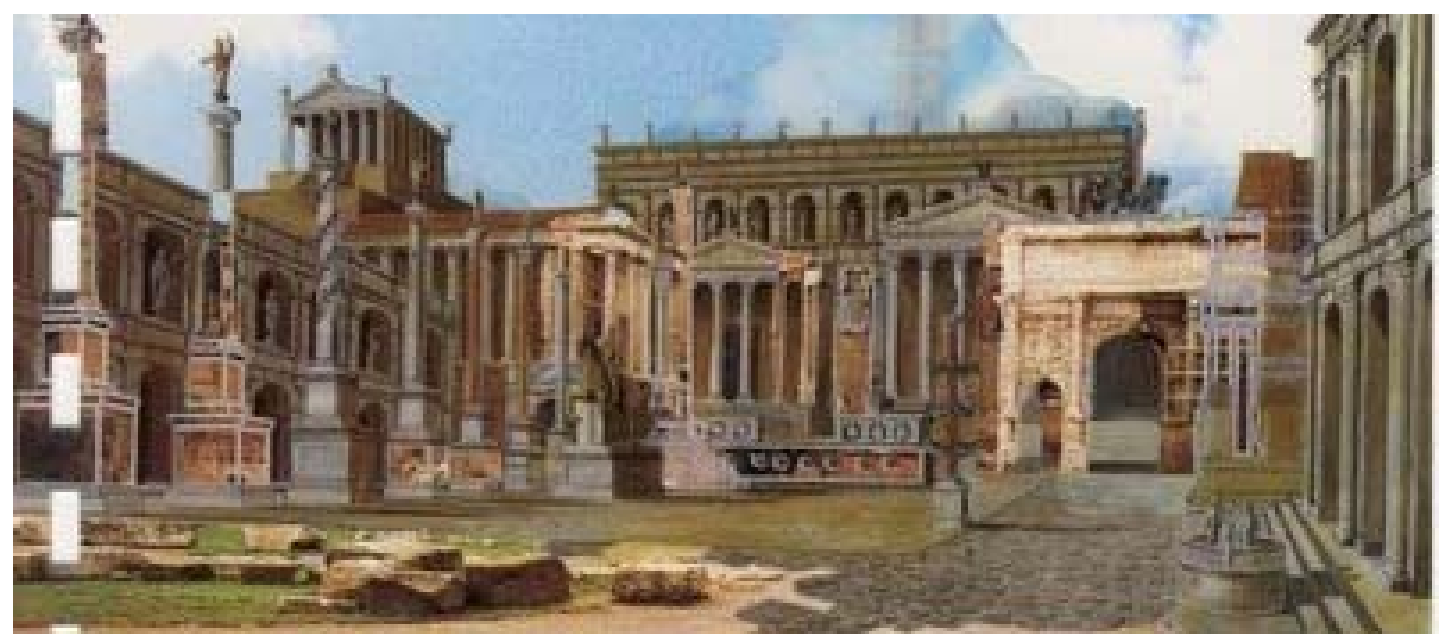

Gambar 9. Forum, Romawi Kuno (Sumber: Architecturoby, 2009)

Kota Romawi memiliki dua kategori pola Forum, yaitu: (1) tumbuh tidak terencana menuju bentuk yang komplek, entitas organik dari waktu ke waktu; (2) dibangun terencana, setelah adanya penghancuran kota Roma tahun 336 SM. Melalui kekuasan kekaisaran, perencanaan yang teratur dan prinsip-prinsip urban diperkenalkan. Area baru dibangun seperti pembangunan Imperial Forum.

Evolusi Forum terdiri dari tiga fase. Fase pertama yaitu pertumbuhan yang tidak terencana dari Forum Romanum, akumulasi dari perkembangan bangunan sedikit demi sedikit dan pembangunan monumen-monumen, pembongkaran dan pembangunan kembali. Fase kedua adalah ketika Kaisar Yulius Caesar dan Agustus mencoba membenahi situasi yang tidak teratur menjadi kota yang teratur dengan tidak secara radikal tetapi melalui tahapan rekonstruksi, bangunan baru dan bangunan tambahan. Bangunan ini disebut sebagai The Republican Forum (Gambar 8), yang berfungsi sebagai pusat kota dan pusat niaga dan sebagai awal mula permukiman Romawi. Biasanya Forum dibangun sepanjang sungai Tiber. Karena lahan yang relatif sempit, luas Forum hanya sekitar 2,5 atau 3 ha yang berdempet-dempet berdekatan satu sama lain. Republican Forum merupakan kumpulan bangunan yang campur aduk yang membentuk ruang yang tidak teratur (Gambar 9). Forum tersusun sebagai indivisual obyek dengan hubungan antar bangunan yang tidak formal. Bangunan penting di dalam Forum adalah bangunan senat atau "curia". Adapun bangunan di Republican Forum merepresentasikan pembangunan kekuatan politik yang semakin meningkat. Peta Forum Romawi selengkapnya dapat dilihat pada Gambar 10. 
Fase ketiga lebih lama, meliputi pembangunan keseluruhan bangunan baru sebagai kumpulan Forum, diluar Forum Romanum. Forum Imperial dirancang dengan menghargai bangunan sebelumnya yang menciptakan keteraturan secara total. The Imperal Forum (27 SM-476 M) (Gambar 11) merupakan perluasan dari Republican Forum sepanjang periode Kekaisaran Romawi. Imperial Forum dibentuk dari alun-alun, rectilinear dan semicircular plaza, masing-masing dibentuk oleh kolom-kolom dan bangunan focal point, yaitu kuil atau basilica yang terletak diakhir ruang. Imperal Forum Mempunyai kejelasan artikulasi ruang dengan kerangka ruang yang teratur dibentuk oleh bangunan-bangunan (Gambar 11).

The plateia $\left(\pi \lambda \alpha \tau \varepsilon^{\prime} \alpha\right)$ Yunani kuno - alun-alun umum atau alun-alun kota - adalah model digunakan sebagai dasar untuk Forum Romawi. Dalam periode imperial gedung-gedung publik besar yang penuh sesak sekitar alun-alun pusat telah berkurang menjadi area terbuka yang berbentuk sebuah persegi panjang sekitar 130 kali 50 meter. Fungsi penting dari Forum, baik Republik Forum atau Imperial Forum adalah untuk melayani sebagai tempat memuncak untuk prosesi militer perayaan yang dikenal sebagai Triumphs dan jamuan makan mewah publik pun terjadi di atas Forum. Gambar 12 berikut adalah ilustrasi Imperial Forum yang berdampingan dengan Republican Forum.

\section{Aquaduct}

Sejalan dengan berkembangnya teknologi pembangunan pada jaman Rowawi, yang pada awalnya dari bahan natural (sangat tergantung bahan, sehingga bentukan yang terjadi memiliki kecenderungan kaku), berkembang menjadi bentuk yang lebih geometris, seperti bentuk arch (busur lengkung), vault dan dome. Bentukan ini diterapkan pada bangunan istana, gudang dan aquaduct. Aquaduct adalah bangunan pada jaman Romawi, yang mencirikan perkembangannya suatu sistemutilitas pertama berupa tangki air untuk keperluan kota (Gambar 13).

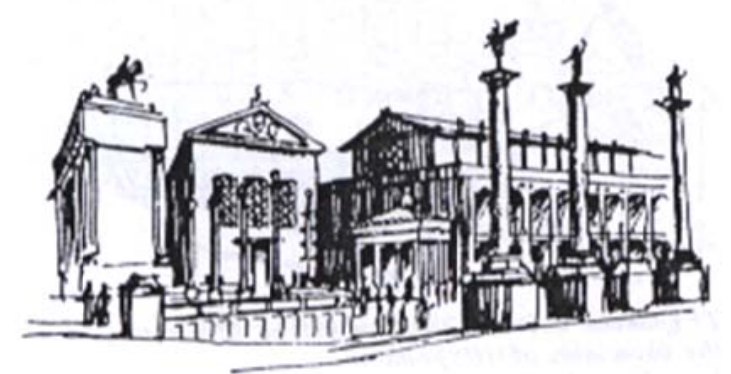

Gambar 8. The Republican forum. Bangunan yang ditengah adalah Curia.

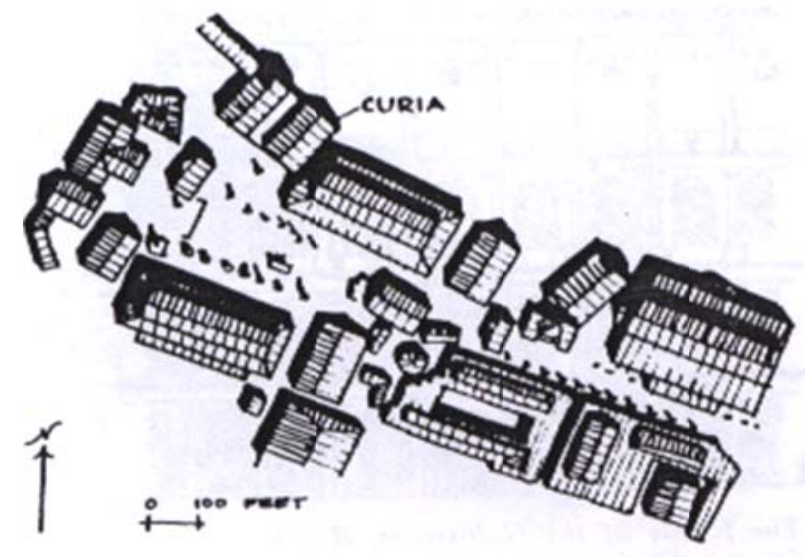

Gambar 9. Gedung-gedung berdempetan tanpa barisan teratur. 


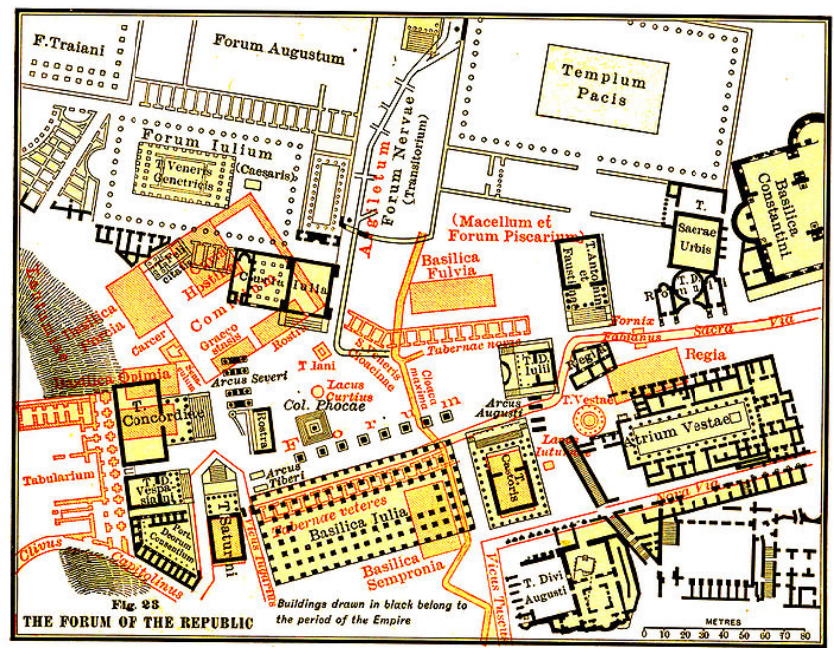

Gambar 10. Peta Forum Romawi (Sumber: Google.com, 2010).

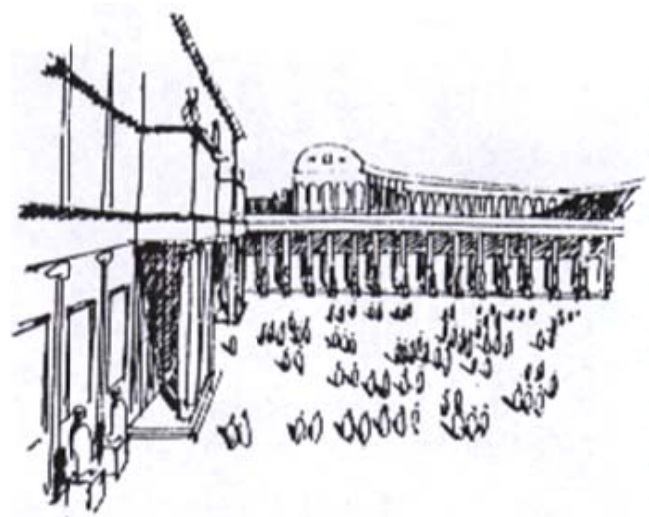

Gambar 11. The Imperial Forum. Bangunan-bangunan didesain untuk membentuk ruang-ruang luas.

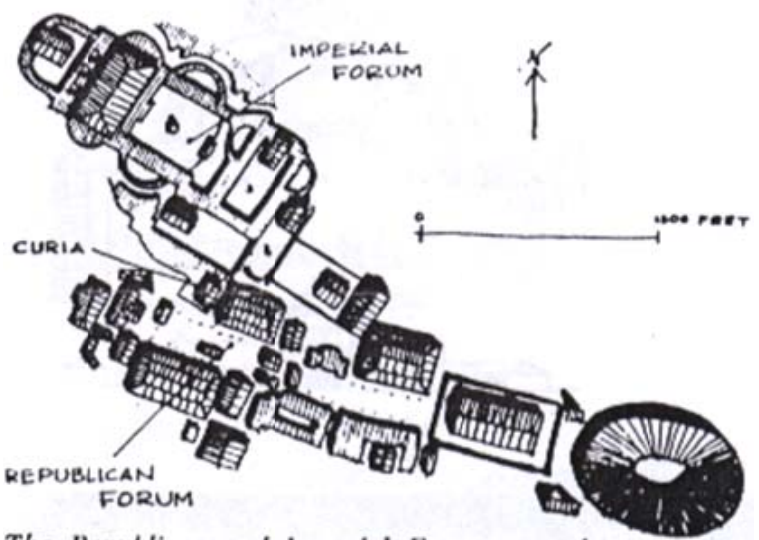

The Republican and Imperial Forums together.

Gambar 12. Imperial Forum berdampingan dengan Republican Forum. 


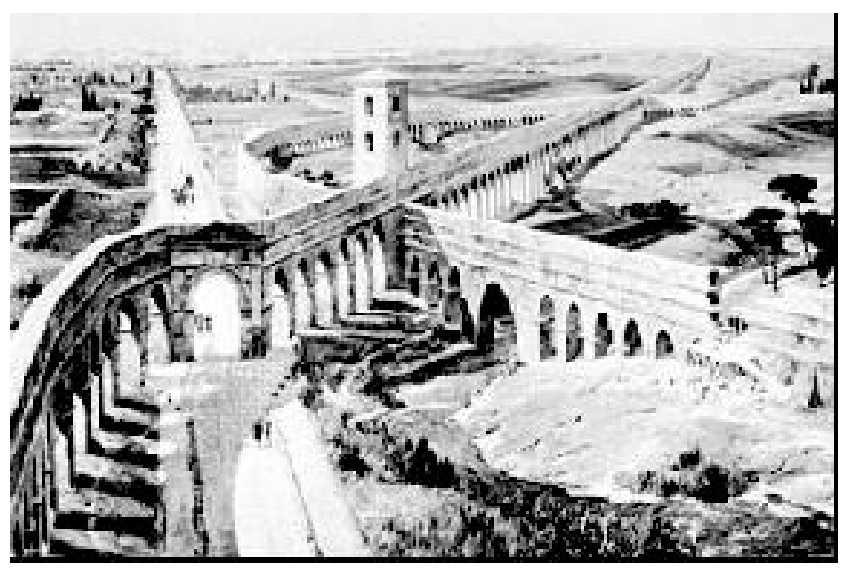

Gambar 13. Aquaduct (Sumber: Google.com, diakses 12 Des 2010).

\title{
PENUTUP
}

Tumbuhnya kota akibat suatu kebudayaan, biasanya dicirikan dengan tumbuhnya pusat jasa yang merupakan urat nadi perekonomian yang menyokong kegiatan kota tersebut. Pusat jasa yang berkembang,biasanya melahirkan suatu community center (pusat komunikasi) yang berupa public facility (fasilitas publik) seperti public space (ruang publik) maupun public building (gedung publik).Pemahaman Barat tentang rancang bangun seperti ini berorientasi ke visi fungsional. Fenomena ini tergambar dari beberapa ilustrasi sejarah yang berkembang pada dunia arsitektur, seperti pertumbuhan Agora di Yunani dan Forum di Romawi. Public space (ruang publik) yang berkembang pada periode klasik ini diperuntukkan untuk kepentingan penguasa.

Agora yang terletak di Athena, Yunani, diatur dalam tatanan ruang kota, dikelilingi oleh bangunan-bangunan penting termasuk pusat rekreasi dan bangunan pemerintahan. Dalam perkembangannya, Agora berfungsi sebagai tempat bermasyarakat, sedangkan pusat pemerintahan sendiri berpindah ke Acropolis.

Di Romawi, fasilitas publik yang berkembang adalah Forum, yang merupakan metamorfosa dari bentuk Agora. Sarana ini dipergunakan oleh penguasa untuk mendemontrasikan kekuasaannya dihadapan masyarakat. Forum dalam perkembangannya, didukung oleh tempat berkembang suatu pemukiman di sekitarnya. Pada akhirnya seperti Agora, Forum berkembang sebagai pusat kegiatan beragama. Perkembangan daerah sekitar secara kosmologis terstruktur memusat ke Forum, sebagai penghormatan masyarakat kepada Pencipta dan penguasa.

\section{DAFTAR PUSTAKA}

\author{
Architecturoby. \\ (2009). \\ Arsitektur \\ Romawi. \\ Diakses \\ dari \\ http://4.bp.blogspot.com/_FbrkfgLXvXo/SdC0P1TmbRI/AAAAAAAAAPE/s- \\ HK2118Pow/s400/9.jpg
}

Bacon, Edmund N. (1976).Design of Cities, (revised ed.).London: Penguin Books.

Kostof, Spiro. (2005). The City Assembled: The Elements of Urban Form Through History. New York:Thames and Hudson. 
Krier, Rob (1979). Urban Space. New York: Rizolli.

Moughtin, Cliff. (1992). Urban Design Street and Square. Oxford: Architectural Press.

Onlyrooms.com. (2009). Places to see in Athens. Diakses 12 Desember 2010 dari http://www.onlyrooms.com/admin/content/fckupload/Agora.jpg

Urban Design. In Wikipedia. Diakes dari http://en.wikipedia.org/wiki/Urban_design 